Volume 2 Nomor 2, Desember 2019

E-ISSN : 2655-7347

\title{
PERLINDUNGAN HUKUM TERHADAP PEMBELI YANG BERITIKAD \\ BAIK DALAM PERJANJIAN PENGIKATAN JUAL BELI (PPJB) (STUDI \\ PUTUSAN PENINJAUAN KEMBALI NOMOR: 534PK/PDT/2017)
}

\author{
Oktaviah \\ (Mahasiswa Program S1 Fakultas Hukum Universitas Tarumanagara) \\ (E-mail: oktavia9910@gmail.com)
}

\section{Dr. Tjempaka, S.H., M.H., M.Kn.}

(Corresponding Author)

(Dosen Tetap Fakultas Ilmu Hukum Universitas Tarumanagara, meraih Sarjana Hukum (S.H.) dari Universitas Tulang Bawang Lampung, dan meraih gelar Magister Ilmu Hukum (M.H.) di Universitas Lampung, serta meraih gelar Magister Kenotariatan (M.Kn.) pada Fakultas Hukum Universitas Diponegoro, serta meraih gelar Doktor (Dr.) pada Fakultas Hukum Universitas Trisakti)

(E-mail: not.tjempaka@gmail.com)

\begin{abstract}
Land has a high value because it is a place where living creatures live and do their activity. Because of the high value humans which are a social creature will defend/maintain their land. The need for land is higher and because of the lack of land, nowadays it is hard to get land. One of the ways to obtain it is by sale and purchase. To guarantee that a sale and purchase between a buyer and a seller is made, it needs a agreement which is called a sale and purchase agreement as an advance agreement even though it a sale and purchase agreement hasn't been regulated in the regulation. A sale and purchase agreement is an agreement that grows in everyday practice in society that, until now is still used in a sale and purchase transaction, to ensure the rights and obligation between the seller and buyer, which the content of the agreement is agreed between the parties as long as it abides to the requirements conditions that are required for the validity of agreements.
\end{abstract}

Keywords: Agreement, Sale, and Purchase.

\section{Pendahuluan}

\section{A. Latar Belakang}

Tanah memiliki nilai yang tinggi, sebab tanah merupakan tempat tinggal bagi setiap makhluk untuk menjalankan segala aktivitas setiap harinya. Karena bernilainya tanah sehingga manusia sebagai makhluk sosial akan mempertahankan tanahnya dengan cara apapun. Untuk mencegah masalah tanah tidak sampai menimbulkan sengketa bahkan 
konflik dalam masyarakat, diperlukan pengaturan, penguasaan, dan penggunaan tanah atau dengan kata lain disebut dengan hukum tanah. ${ }^{1)}$

Tanggal 24 September 1960 sebagai tanggal disahkannya UndangUndang Nomor 5 tahun 1960 tentang Peraturan Dasar Pokok-Pokok Agraria yang selanjutnya disebut UUPA. Dalam rangka menjamin kepastian hak dan kepastian hukum atas tanah, UUPA telah menggariskan adanya keharusan untuk melaksanakan pendaftaran tanah di seluruh Indonesia, sebagaimana yang terdapat dalam Pasa1 19 Ayat (1) UUPA, yang menyatakan bahwa: "Untuk menjamin kepastian hukum oleh Pemerintah diadakan pendaftaran tanah di seluruh wilayah Republik Indonesia menurut ketentuan-ketentuan yang diatur dengan Peraturan Pemerintah."

Untuk hak-hak atas tanah, hak milik atas satuan rumah susun, hak pengelolaan, dan tanah wakaf yang telah didaftarkan dalam buku tanah dan memenuhi syarat diberikan tanda bukti haknya diterbitkan sertipikat. Sertipikat diterbitkan oleh Kantor Pertanahan Kabupaten/Kota. Sertipikat diterbitkan untuk kepentingan pemegang hak yang bersangkutan sesuai dengan data fisik dan data yuridis yang telah didaftarkan dalam buku tanah. Sertipikat hanya boleh diserahkan kepada pihak yang namanya tercantum dalam buku tanah yang bersangkutan sebagai pemegang hak atau kepada pihak lain yang dikuasakan olehnya. ${ }^{2)}$

Cara untuk peroleh tanah adalah dengan cara melalui jual beli. Jual beli tanah merupakan hal yang sering terjadi dalam kehidupan sehari-hari di masyarakat. Istilah jua1 beli disebutkan dalam Pasa1 26 UUPA yaitu yang menyangkut jual beli hak milik atas tanah. Pasa1-Pasa1 lainnya tidak ada kata yang menyebutkan jua1-beli, tetapi hanya disebutkan sebagai dialihkan. Pengertian dialihkan menunjukan suatu perbuatan hukum yang disengaja untuk memindahkan hak atas tanah kepada pihak

\footnotetext{
1) K. Wantijk Saleh, Hak Anda Atas Tanah, (Jakarta: Ghalia Indonesia, 1982), hal.7.

2) Urip Santoso, Pejabat Pembuat Akta Tanah: Perspektif Regulasi, Wewenang, dan Sifat Akta, Cetakan ke-1, (Jakarta: Prenadamedia Group, 2016), hal.15.
} 
E-ISSN : 2655-7347

lain. Jadi, meskipun dalam Pasa1 hanya disebutkan dialihkan, termasuk salah satunya adalah perbuatan hukum pemindahan hak atas tanah karena jua1 beli. ${ }^{3)}$

Dalam Pasa1 1458 Kitab Undang-Undang Hukum Perdata yang selanjutnya disebut KUH Perdata menyatakan bahwa: "Jual beli itu dianggap telah terjadi antara kedua belah pihak, seketika setelahnya orang-orang ini mencapai sepakat tentang kebendaan tersebut dan harganya, meskipun kebendaan itu belum diserahkan, maupun harganya belum dibayar".

Meski demikian jual beli tanah yang terdapat di dalam Pasa1 5 UUPA berbeda dengan Pasal 1458 KUH Perdata bahwa dalam hukum agraria yang berlaku atas bumi, dan ruang angkasa ialah hukum adat. Berdasarkan hukum adat perjanjian jual beli tanah merupakan perjanjian yang bersifat "Terang" dan "Tunai". Disebut "Terang" disini karena dilaksanakan dihadapan kepala adat, supaya diketahui oleh umum. Menurut Pasa1 37 Peraturan Pemerintah Nomor 24 tahun 1997 tentang Pendaftaran Tanah, jua1 beli tanah dapat dilaksanakan jika aktanya dibuat dihadapan Pejabat Pembuat Akta Tanah yang selanjutnya disebut PPAT yang berwenang. Dalam hukum adat tersebut, sifat "Terang" disini karena harus dilakukan dihadapan PPAT, pejabat yang ditunjuk khusus oleh pemerintah yang wilayah kerjanya sesuai dengan lokasi tanah yang akan dijua1. Disebut "Tunai" disini terjadi bersamaan antara perbuatan penyerahan tanah dan pembayaran nilai harga tanah, artinya jua1 beli tersebut telah terpenuhi seketika ketika tanah telah diserahkan.

Praktiknya pihak penjual dan pembeli menginginkan bahwa barang atau benda yang akan menjadi objek jual beli dapat diserahkan dan diterima oleh masing-masing pihak, namun dalam praktiknya ada perjanjian jual beli di mana objeknya belum dapat dialihkan kepada

3) Adrian Sutedi, Peralihan Hak Atas Tanah Dan Pendaftarannya, (Jakarta: Sinar Grafika, 2008), hal.76. 
calon pembeli, karena belum dilengkapi dokumen-dokumen yang berkaitan dengan objek tersebut dan/atau harga barang belum dilunasi secara penuh oleh calon pembeli. Sehingga untuk menjamin adanya jua1 beli atas tanah antara penjual dan pembeli dilakukan suatu perjanjian yang disebut Perjanjian Pengikatan Jua1 Beli yang selanjutnya disebut PPJB sebagai perjanjian pendahuluan meskipun PPJB itu belum diatur dalam undang-undang, yang hingga kini dalam praktik jual beli tanah dilakukan terlebih dahulu untuk menjamin hak dan kewajiban antara penjual dan pembeli yang isi dari PPJB tersebut disepakati antar para pihak asalkan memenuhi syarat-syarat sahnya suatu perjanjian. Ada empat syarat yang mengatur tentang sahnya perjanjian adalah sebagai berikut: ${ }^{4)}$

1. Adanya kesepakatan antara para pihak;

2. Kecakapan dalam melakukan perbuatan hukum;

3. Adanya objek; dan

4. Adanya kausa yang halal.

Selain di dalam Pasa1 1320 KUH Perdata, terdapat pula peraturan tentang kekuatan mengikat suatu perjanjian yang didasarkan pada sistem terbuka yang dianut dalam hukum perjanjian, sistem terbuka ini mengandung suatu asas kebebasan dalam membuat perjanjian yang terdapat di dalam Pasal 1338 Ayat (1) KUH Perdata, menyatakan bahwa: "Semua perjanjian yang dibuat secara sah berlaku sebagai undang-undang bagi mereka yang membuatnya". Dan menurut Pasa1 1338 Ayat (3) KUH Perdata, menyatakan bahwa: "Semua perjanjian harus dilaksanakan dengan itikad baik". Ini merupakan salah satu sendi yang penting dalam hukum perjanjian dimana hukum selalu mengejar dua tujuan yaitu menjamin kepastian (ketertiban) dan memenuhi tuntutan keadilan. Kepastian hukum menghendaki supaya apa yang dijanjikan harus dipenuhi (ditepati), dan berperilaku adil dalam menuntut

4) Salim HS, Perkembangan Hukum Kontrak diluar KUH Perdata (a), (Jakarta: Raja Grafindo Persada, 2007), hal.17. 
pemenuhan janji itu, sehingga maksud itikad baik dalam Pasal 1338 Ayat (3) itu terpenuhi.

Penulis tertarik untuk membahas suatu kasus yang berawal dari Alie Santoso (almarhum) yang merupakan orang tua kandung dari Koko Purnomo Santoso pada tahun 1972 membeli beberapa bidang tanah. Bahwa antara tahun 1978 sampai dengan tahun 1980 karena ada Peraturan Gubernur yang kemudian secara lebih lanjut terdapat dalam Pasa1 7 jo Pasa1 17 Undang-Undan Pokok Agraria tentang Kepemilikan Tanah Tidak Boleh Dari $5000 \quad \mathrm{M}^{2}$ dalam satu bidang sehingga didaftarkannya tanah-tanah tersebut diantaranya menjadi 6 (enam) Girik atas nama saudara dan karyawannya. Surat dan Girik serta Fisik tanah tersebut tetap dikuasai Alie Santoso (almarhum). Sekitar tahun 1990, Girik-girik tersebut di atas oleh Alie Santoso (almarhum) diatasnamakan kembali dengan Akta Jua1 Beli (AJB) ke anak dan Karyawannya. Dalam rangka kerjasama dengan PT. Summarecon Agung girik-girik tersebut diserahkan ke Kantor Badan Pertanahan Nasional Jakarta Timur selanjutnya disebut BPN Jakarta Timur dalam rangka permohonan penyertifikatan atas tanah-tanah tersebut. Tanda terima dari BPN Jakarta Timur diterima dan disimpan oleh Alie Santoso (almarhum). Namun kerjasama Alie Santoso dengan PT. Summarecon Agung gagal.

Kemudian mengetahui kerjasama itu gagal Koko Purnomo Santoso membuat Surat Tanda Penerimaan Laporan Kehilangan Surat/Barang dari Kepolisian atas tanda terima girik dari Alie Santoso ke BPN Jakarta Timur dalam rangka pengurusan Sertifkat Tanah, dan dengan dasar surat kehilangan itulah Koko Purnomo Santoso berhasil mengambil asli girikgirik yang ada di BPN Jakarta Timur. Koko Purnomo Santoso menghubungi nama-nama yang ada pada girik tersebut yakni Betty Widya Handayani, Wahyuni, Suhandi dan Thung Arifin, Koko Purnomo Santoso sudah disiapkan sebelumnya dibuatkan akta kuasa menjual dari Betty Widya Handayani, Wahyuni, Suhandi kepada Koko Purnomo Santoso. 
Setelah mendapat Akta Kuasa Menjua1 Koko Purnomo Santoso melakukan Pengikatan Jua1 Beli dengan PT. Intan Plaza Andika atas 7 (Tujuh) bidang tanah berdasarkan Akta PPJB, yang dibuat oleh Notaris Buntario Tigris Darmawa Ng, S.H., S.E., M.H. di Jakarta selanjutnya disebut Notaris, kesemuanya beralamat di Jalan Raden Inten, Duren Sawit, Jakarta Timur dan telah dibayar lunas oleh PT. Intan Plaza Andika kepada Koko Purnomo Santoso dengan cara ditransfer ke rekening Koko Purnomo Santoso oleh Bagian Keuangan PT. Intan Plaza Andika, Akta PPJB tersebut antara lain sebagai berikut:

1. PPJB Nomor 8, Girik Nomor 1563, Persil 448, Luas $1.685 \mathrm{~m} 2$, atas nama Koko Purnomo Santoso.

2. PPJB Nomor 8, Girik Nomor 1563, Persil 527, Luas 3.045 m2, atas nama Koko Purnomo Santoso.

3. PPJB Nomor 8, Girik Nomor 1571, Persi1 448, Luas 2.000 m2, atas nama Koko Purnomo Santoso.

4. PPJB Nomor 9, Girik Nomor 1564, Persi1 449, Luas 3.358 m2, atas nama Wahyuni.

5. PPJB Nomor 10, Girik Nomor 1561, Persil 457, Luas $1.618 \mathrm{~m} 2$, atas nama Betty Widyahandajani.

6. PPJB Nomor 11, Girik Nomor 1570, Persi1 457, Luas 2.967 m2, atas nama Betty Widyahandajani.

7. PPJB Nomor 12, Girik Nomor 356, Persi1 137, Luas 3.903 m2, atas Suhandi.

Akibat dari tindakan Koko Purnomo Santoso, Alie Santoso mengajukan Surat Pengaduan ke Mabes Polri. Koko Purnomo Santoso terbukti menurut hukum secara sah dan meyakinkan melakukan kejahatan menjual tanah milik orang lain dan menempatkan keterangan palsu pada akta autentik dan dihukum penjara selama 4 (empat) tahun dalam putusan Nomor 767/K/Pid/2008.

Pada tanah objek sengketa tersebut PT. Intan Plaza Andika belum bisa balik namakan tanah obyek sengketa ke atas nama Penggugat karena 
pada saat ingin balik nama ditolak oleh BPN Jakarta Timur karena tidak ada Surat Keterangan dari Lurah Duren Sawit dan menolak menerbitkan Surat Keterangan tersebut karena ada pemblokiran sebab Koko Purnomo Santoso terbukti dinyatakan bersalah menjual tanah milik orang lain dan menempatkan keterangan palsu pada akta autentik. Sehingga mengakibatkan timbulnya kerugian bagi pihak PT. Intan Plaza Andika sebagai pembeli. Sehingga PT. Intan Plaza Andika sebagai penggugat mengajukan gugatan.

Dalam gugatan yang diajukan PT. Intan Plaza Adika disebut sebagai Pengugat pada Pengadilan Negeri Jakarta Timur Nomor: 117/Pdt.G/2014/PN.Jkt.Tim. dimenangkan oleh Pengugat dan Upaya Hukum Banding yang diajukan oleh para Tergugat atau Para Pembanding pada Pengadilan Tinggi DKI Jakarta Nomor: 117/PDT/2015/PT.DKI. tetap dimenangkan oleh Penggugat atau Terbanding. Namun demikian pada Upaya Hukum Kasasi Nomor 17K/Pdt/2016. yang diajukan Koko Purnomo Santoso (Tergugat I), Wahyuni (Tergugat II) dan Betty Widyahandajani (Tergugat III) atau disebut Para Pemohon Kasasi dalam putusannya mengabulkan permohonan kasasi dari Para Pemohon Kasasi Koko Purnomo Santoso, Wahyuni dan Betty Widyahandajani dan membatalkan Putusan Pengadilan Tinggi Jakarta Nomor 117/PDT/2015/PT.DKI. tangga1 8 April 2015 yang menguatkan Putusan Pengadilan Negeri Jakarta Timur Nomor: 117/Pdt.G/2014/PN.Jkt.Tim. tangga1 28 Oktober 2014 yang mengakibatkan timbulnya kerugian bagi pihak Penggugat sebagai pembeli. Sehingga PT. Intan Plaza Adika mengajukan upaya hukum luar biasa yaitu Peninjauan Kembali Nomor: 534 PK/Pdt/2017 berikut buktibukti baru yang ada. Dimana salah satu bukti barunya Koko Purnomo Santoso pernah melakukan transaksi jua1 beli dengan PT. Summarecon Agung dan jua1 beli tersebut berjalan lancar. Serta dari tahun 1990 hingga pada tahun 2005 yang artinya selama kurang lebih 15 (lima belas) tahun, objek sengketa tidak pernah ada pihak lain yang mengakui sebagai 
pemiliknya, termasuk Alie Santoso (ayah kandung Koko) dan juga tidak ada pihak yang menguasai tanah-tanah tersebut.

Karena itu penulis ingin membahas masalah dalam sebuah penulisan ini dengan judul PERLINDUNGAN HUKUM TERHADAP PEMBELI YANG BERITIKAD BAIK DALAM PERJANJIAN PENGIKATAN JUAL BELI (PPJB) (STUDI PUTUSAN PENINJAUAN KEMBALI NOMOR: 534PK/PDT/2017).

\section{B. Perumusan Masalah}

Berdasarkan uraian di atas yang menjadi pokok permasalahan penulisan ini adalah bagaimana Perlindungan Hukum Terhadap Pembeli Yang Beritikad Baik Dalam Perjanjian Pengikatan Jual Beli (PPJB) (Studi Putusan Peninjauan Kembali Nomor: 534PK/Pdt/2017).

\section{Pembahasan}

Berdasarkan beberapa hal yang telah dijelaskan dalam latar belakang maka penulis berpendapat bahwa hal yang menjadi titik tolak dalam kasus ini, seperti yang sudah penulis jelaskan, Terjadinya perjanjian antara para pihak Koko Purnomo Santoso dan PT. Intan Plaza Adika yang dituangkan kedalam akta PPJB yang dibuat di hadapan Notaris tanggal 1 Desember 2005. Akta yang dibuat oleh notaris berisi mengenai keterangan resmi dari pejabat berwenang, tentang apa yang dia lihat dan saksikan dihadapannya mengenai uraian atau keterangan yang dikehendaki oleh para pihak yang diceritakan di hadapan Notaris. Penjabaran atau keterangannya dimasukan dalam bentuk akta notaris dalam kasus ini dituangkan dalam akta PPJB. Mengenai apa yang seorang notaris lihat dan saksikan dihadapannya antara Koko Purnomo Santoso dengan PT. Intan Plaza Adika yang bersama-sama datang ke hadapan notaris untuk mengikatkan diri dengan membuat suatu akta PPJB dengan uraian dan keterangan para pihak jelaskan dan Koko Purnomo Santoso pihak penjual sebagai pemiliki atas objek Tanah Jua1 Beli dengan surat-surat asli atas nama Koko Purnomo Santoso serta juga dengan kuasa jua1 dari 
Volume 2 Nomor 2, Desember 2019

E-ISSN : 2655-7347

Wahyuni, Betty Widyahandayani dan Suhandi sehingga dengan kuasa jua1 tersebut Koko Purnomo Santoso memiliki kewenangan yang sama dengan pemilik Tanah Objek Jual Beli tersebut. Sehingga berdasarkan kewenangannya dalam Pasal 15 Ayat (2) Huruf f UUJN, bahwa seorang Notaris berwenang membuat akta yang berkaitan dengan pertanahan tersebut.

Dimana antara PT. Intan Plaza Adika dan Koko Purnomo Santoso membuat akta PPJB yang merupakan suatu jenis perjanjian pendahuluan yang tumbuh dan berkembang dalam praktek sehari-hari dan bentuknya bebas. Sehingga dibuat agar memberikan perlindungan terhadap hak dan kewajiban antara PT. Intan Plaza Adika dengan Koko Purnomo Santoso karena dalam hal mengenai jua1 beli tanah terdapat syarat-syarat yang belum dapat terpenuhi dalam membuat akta peralihan yaitu Akta Jua1 Beli dan dalam pembuatan akta peralihan harus dilakukan di depan pejabat yang berwenang sesuai dengan wilayah objek yang akan dilakukan jual beli dalam hal ini Notaris hanya berwenang di wilayah Jakarta Pusat dan Tanah Objek Jua1 Beli berada di wilayah Jakarta Timur sehingga menurut Penulis akta PPJB ini dibuat untuk mengikat antar para pihak agar melindungi calon penjual dan calon pembeli agar calon penjual tidak mengalihkan objek jua1 beli kepada pihak lainnya, dan calon pembeli tidak membatalkan jual beli yang akan dibuat antara keduanya.

Mengenai PPJB sendiri belum diatur secara khusus dalam KUH Perdata, akan tetapi tetap tunduk pada ketentuan-ketentuan umum dalam Buku III KUH Perdata mengenai Perikatan. Dimana perjanjian yang menurut Pasa1 1313 KUH Perdata yang menyatakan "Suatu perjanjian adalah suatu perbuatan dengan mana satu orang atau lebih mengikatkan dirinya terhadap satu orang lain atau lebih." Jika dilihat kasus antara PT. Intan Plaza Adika dengan Koko Purnomo Santoso ini para pihak saling mengikatkan diri kedalam Akta Perjanjian Pengikatan Jua1 Beli (PPJB) Nomor 8, 9, 10, 11, 12 yang dibuat di hadapan Notaris. di Jakarta tangga1 1 Desember 2005 atas 7 (tujuh) bidang tanah. 
Volume 2 Nomor 2, Desember 2019

E-ISSN : 2655-7347

Jika dilihat berdasarkan perjanjian jua1 beli antara PT. Intan Plaza Adika dengan Koko Purnomo Santoso penulis melihat dasar terjadinya permasalahan tersebut berawal dari suatu perjanjian, dalam perjanjian sendiri dikenal beberapa asas penting, yaitu: ${ }^{5)}$

a. Asas Pacta Sunt Servanda

Setiap pihak yang mengadakan perjanjian wajib mentaati perjanjian yang telah dibuatnya karena perjanjian yang dibuat berlaku sebagai undang-undang untuk para pihak.

b. Asas Konsensualisme

Perjanjian yang dibuat para pihak ada sejak muncul kata sepakat diantaranya para pihak yang artinya perjanjian itu sah dan mempunyai akibat hukum sejak saat tercapainya kata sepakat antara para pihak mengenai pokok isi dari perjanjian.

c. Asas Obligator

Perjanjian yang dibuat oleh para pihak itu baru dalam tahap menimbulkan hak dan kewajiban saja, belum memindahkan hak milik, hak milik baru pindah apabila diperjanjikan tersendiri yang disebut perjanjian yang bersifat kebendaan

d. Asas Itikad Baik

Suatu perjanjian yang dibuat hendaknya tidak merugikan kepentingan kedua belah pihak.

e. Asas Kebabasan Berkontrak

Dalam asas ini para pihak diberikan kebebasan yang seluas-luasnya untuk membuat perjanjian dengan siapa saja, apapun bentuknya, dan berisi apa saja selama tidak bertentangan dengan undang-undang, ketertiban umum, dan kesusilaan.

Dari beberapa asas-asas perjanjian tersebut Penulis berpendapat bahwa PPJB atas 7 (tujuh) bidang tanah antara PT. Intan Plaza Adika dengan Koko Purnomo Santoso berdasarkan asas pacta sunt servanda jelas telah berjalan

5) Abdulkadir Muhammad, Hukum Perikatan, (Bandung: Citra Aditya Bakti, 1990), hal.84. 
dimana pihak PT. Intan Plaza Adika dan pihak Koko Purnomo Santoso masing-masing pihak memegang penuh nilai PPJB sebagai undang-undang yang nantinya pihak Koko Purnomo Santoso harus mengikuti segala hal yang diatur dalam perjanjian tersebut dengan PT. Intan Plaza Adika, sebaliknya juga pihak PT. Intan Plaza Adika harus mengikuti segala hal yang diatur dalam perjanjian tersebut. Dalam hal ini segala aturan yang mengikat pihak PT. Intan Plaza Adika dengan pihak Koko Purnomo Santoso akan berakhir jika tujuan akhir dari perjanjian tersebut telah dipenuhi.

Perjanjian jua1 beli atas 7 (tujuh) bidang tanah antara PT. Intan Plaza Adika dengan Koko Purnomo Santoso sebenarnya sudah ada sejak muncul kata sepakat, dalam kronologi permasalahan asas konsensualisme jelas ada ketika pihak PT. Intan Plaza Adika dengan Koko Purnomo Santoso mendatangi kantor Notaris di Jakarta tangga1 1 Desember 2005 menceritakan maksud dan tujuan yang menjadi awal terbentuknya suatu kesepakatan sebelum ditumpahkan kedalam suatu akta PPJB.

Asas Obligator yang dimaksud dalam PPJB telah timbul hak dan kewajiban para pihak yang dimana pihak PT. Intan Plaza Adika memiliki kewajiban untuk membayar harga yang telah disepakati. Selain itu Pihak Koko Purnomo Santoso juga wajib menyerahkan dokumen-dokumen yang diperlukan berkaitan dengan jua1 beli atas 7 (tujuh) bidang tanah dan menjamin tanah tersebut tidak dalam sengketa dan menjamin bahwa tanah tersebut dapat dimohonkan dan diterbitkan sertifikat atas nama pihak PT. Intan Plaza Adika sebagai haknya selaku pembeli dan sebagainya berdasarkan perjanjian yang telah dibuat. Sedangkan Koko Purnomo Santoso memiliki hak untuk memperoleh harga yang telah disepakati sebagai pembayaran atas jua1 beli tanah tersebut.

Menurut pendapat penulis bahwa pihak PT. Intan Plaza Adika memenuhi asas itikad baik dalam PPJB karena dalam pelaksanaannya PT. Intan Plaza Adika memiliki itikad baik yaitu dengan melakukan pembayaran secara lunas kepada pihak Koko Purnomo Santoso sesuai dengan harga yang telah disepakati dan dilakukan di hadapan Notaris disamping itu pihak Koko 
Purnomo Santoso juga telah menyerahkan surat-surat asli tanah tersebut kepada PT. Intan Plaza Adika sehingga PT. Intan Plaza Adika sudah memegang surat-surat asli atas tanahnya.

Selain itu para pihak juga harus memenuhi asas kebebasan berkontrak, hal ini berlaku apabila ada kesepakatan diantara para pihak. Demikian halnya juga dengan pihak PT. Intan Plaza Adika dengan Koko Purnomo Santoso, mereka bebas melakukan perjanjian dengan siapapun dan bebas menentukan isi perjanjian, seperti halnya PPJB atas 7 (tujuh) bidang tanah yang mewajibkan hak dan kewajiban para pihak terpenuhi, meskipun para pihak diberikan kebebasan untuk membuat segala isi perjanjian namun tetap harus memperhatikan ketentuan, kepatutan, kebiasaan, dan undang-undang seperti yang diatur dalam Pasa1 1339 KUH Perdata.

Untuk memenuhi syarat-syarat sahnya suatu perjanjian maka berlaku ketentuan Pasa1 1320 KUH Perdata, yaitu:

1. Kesepakatan dari para pihak.

2. Kecakapan dalam membuat suatu perikatan.

3. Suatu hal tertentu.

4. Suatu sebab yang halal

Keempat syarat tersebut merupakan syarat mutlak yang harus dipenuhi selama suatu perjanjian agar suatu perjanjian dianggap sah. Dari ketentuan diatas dapat ditarik beberapa unsur yang mendasari adanya suatu perjanjian yaitu Dua syarat pertama kesepakatan dan kecakapan, dinamakan syarat subjektif, karena perihal orang-orangnya atau subjeknya yang mengadakan perjanjian, sedangkan dua syarat yang terakhir yaitu suatu hal tertentu dan sebab yang halal dinamakan syarat objektif karena mengenai isi perjanjian sendiri atau objek dari perbuatan hukum yang dilakukan dalam perjanjian.

Mengenai syarat pertama kesepakatan dalam hal ini terlihat dari tindakan hukum penjual Koko Purnomo Santoso dan pembeli PT. Intan Plaza Adika dalam melakukan PPJB yang dibuat para pihak dan objek perjanjian yaitu 7 (tujuh) bidang tanah yang beralamat di Jalan Raden Inten, Duren Sawit, Jakarta Timur, yang dibuat di hadapan Notaris di Jakarta tangga1 1 Desember 
2005, yang nantinya akan menimbulkan hak dan kewajiban antara penjual dan pembeli dalam hal ini menurut Penulis telah terjadi kesepakatan antara para pihak yaitu antara PT. Intan Plaza Adika dengan Koko Purnomo Santoso karena para pihak telah menuangkan ke dalam akta PPJB yang telah di tandatangani oleh para pihak.

Dalam hal ini syarat kedua kecakapan, para pihak yang membuat PPJB harus cakap dalam melakukan perbuatan hukum, mengenai syarat ini para pihak yaitu Koko Purnomo Santoso dan PT. Intan Plaza Adika diwakili oleh pihak yang bertanggung jawab secara hukum atas perusahaan tersebut telah memenuhi syarat cakap dalam segi umur, tidak dibawah pengampuan atau sehat pikirannya.

Dalam posisi kasus ini penulis berpendapat bahwa pihak Koko Purnomo Santoso sebagai penjual dan PT. Intan Plaza Adika sebagai pembeli telah memenuhi semua syarat kecakapan dalam perbuatan hukum perjanjian yang disebutkan dalam Pasa1 1330 KUH Perdata, dan bagi PT. Intan Plaza Adika yang menandatangani perjanjian merupakan pihak yang bertanggung jawab secara hukum atas perusahaan.

Syarat yang ketiga adalah suatu hal tertentu, dalam hal PPJB yang dibuat para pihak jika dilihat dari perjanjannya sudah jelas bahwa perjanjian ini berisikan perihal jual beli atas 7 (tujuh) bidang tanah beralamat di Jalan Raden Inten, Duren Sawit, Jakarta Timur antara PT. Intan Plaza Adika sebagai pembeli dan Koko Purnomo Santoso sbagai penjual, hal ini jelas objek yang nantinya akan dijua1 adalah 7 (tujuh) bidang tanah.

Mengenai syarat yang ke empat yaitu sebab yang halal, syarat keempat ini merupakan suatu sebab pihak PT. Intan Plaza Adika sebagai pembeli dan Koko Purnomo Santoso sebagai penjual melakukan PPJB tersebut, sebab dalam hal ini bukanlah sebab dalam arti yang menyebabkan atau mendorong orang atau para pihak membuat suatu perjanjian melainkan sebab dalam arti isi PPJB tersebut yang menggambarkan tujuan yang akan dicapai para pihak yang mengadakan perjanjian tersebut. Dalam ketentuan syarat keempat sebab yang halal menjelaskan bahwa perjanjian yang dibuat pihak PT. Intan Plaza 
Volume 2 Nomor 2, Desember 2019

E-ISSN : 2655-7347

Adika dengan pihak Koko Purnomo Santoso tidak boleh mengandung suatu sebab yang palsu dan sebab yang terlarang dimana para pihak harus menjalankan perjanjian dengan itikad baik dan tidak bertentangan dengan undang-undang, ketertiban umum, dan kesusilaan seperti yang diatur dalam Pasal 1338 Ayat (3) KUH Perdata, disamping itu perjanjian juga harus mengandung suatu sebab yang halal karena perjanjian yang dilakukan tanpa sebab yang halal dilarang oleh Pasa1 1335 KUH Perdata.

Dalam kausus ini menurut Penulis meskipun pihak Koko Purnomo Santoso selaku penjual terbukti dinyatakan bersalah menjual tanah milik orang lain dan menempatkan keterangan palsu pada akta autentik pada tahun 2007. Dalam putusan hakim Koko Purnomo Santoso pun dijatuhi hukuman pidana kurang lebih 4 (empat) tahun yang dituangkan dalam putusan Nomor 767/K/Pid/2008 akan tetapi PPJB antara PT. Intan Plaza Adika dengan Koko Purnomo Santoso yang dibuat pada tangga1 1 Desember 2005 di hadapan Notaris di Jakarta, pada saat melakukan perjanjian jual beli 7 (tujuh) bidang tanah yang 3 (tiga) bidang tanah diantaranya atas nama Koko Purnomo Santoso dan 4 (empat) bidang tanah lainya atas nama Wahyuni, Betty Widyahandayani, Suhandi dan dalam Pengikatan Jual beli tersebut Koko Purnomo Santoso telah mendapatkan Kuasa dari Wahyuni, Betty Widyahandayani dan Suhandi untuk menjual atau melepaskan hak kepada siapa saja baik sebagian atau seluruhnya terhadap tanah-tanah tersebut. Koko Purnomo Santoso selaku pemilik dan penerima kuasa tersebut juga menyerahkan surat-surat asli kepada pembeli dan bukan surat-surat salinan, sehingga menurut penulis PT. Intan Plaza Adika sebagai pembeli tidak merasa ada suatu sebab yang tidak halal dalam hal jual beli ini dan perjanjian ini sesuai dengan syarat sahnya perjanjian.

Itikad baik merupakan inti dalam melaksanakan perjanjian. Para pihak dalam membuat maupun melaksanakan perjanjian harus memperhatikan asas itikad baik, yaitu dalam melakukan perjanjian tersebut harus mengindahkan norma-norma kepatuhan dan kesusilaan. Perjanjian antara PT. Intan Plaza Adika dengan Koko Purnomo Santoso dalam PPJB Nomor 8, 9, 10, 11, 12 
E-ISSN : 2655-7347

terhadap Tanah Objek Jua1 Beli yang dibuat, juga telah secara tegas Koko Purnomo Santoso menjamin kepada PT. Intan Plaza Adika tentang hal-hal antara lain: menjamin tanah tersebut tidak dalam status sengketa dan menjamin bahwa tanah tersebut dapat dimohonkan dan diterbitkan sertifikat atas nama pihak Penggugat dan sebagainya. Mengacu kepada tindakan Koko Purnomo Santoso yang melakukan perbuatan pidana atas Tanah Objek Jua1 Beli sehingga apa yang diperjanjikan oleh Koko Purnomo Santoso di atas tidak dapat dipenuhi padahal PPJB tersebut dibuat dihadapan Notaris yang melihat bahwa Koko Purnomo Santoso memang kapasitasnya yang sah sebagai pemilik serta cara perolehannya hak atas tanahnya dari Alie Santoso kepada Koko Purnomo Santoso juga sah menurut ketentuan yang berlaku dan ataupun sebagai penerima kuasa dan atas surat-surat asli Tanah Objek Jua1 Beli juga sudah berada pada PT. Intan Plaza Adika sebagai pembeli juga sudah melaksanakan pembayaran sesuai dengan harga yang dijanjikan yang artinya PT. Intan Plaza Adika telah melaksanakan apa yang diperjanjikan dan dapat dikatakan sebagai pembeli yang beritikad baik yang harus dilindungi karena menyangkut hak atas tanah yang menjadi objek jual beli.

Berdasarkan Surat Edaran Mahkamah Agung Republik Indonesia (SEMA) Nomor 5 Tahun 2014 mengenai kriteria pembeli yang beritikad baik terhadap PT. Intan Plaza Andika telah memenuhi sebagai pembeli yang beritikad baik karena Koko Purnomo Santoso adalah pemiliki hak atas tanah yang menjadi objek jua1 beli, sesuai dengan bukti kepemilikannya dan diserahkannya dokumen-dokumen kepemilikannya yang asli dan bukan salinan, tanah tersebut tidak sedang dijaminkan ataupun dalam status disita, serta dilakukan secara tunai dan terang, meskipun tidak di depan Kepala Desa setempat, melainkan dihadapan Notaris sebagai Pejabat Umum setelah Kepala Desa setempat memberikan Surat Keterangan bahwa objek adalah benar milik Koko Purnomo Santosa yang artinya pembeli juga melakukan upaya untuk mecari tahu dan mencermati secara patut data fisik dan data yuridis sebelum dan saat jual beli dilakukan. Sehingga PT. Intan Plaza Adika 
E-ISSN : 2655-7347

tidak dapat menduga jika ada suatu kekeliruan dalam peralihan hak dari pemilik asal kepada Koko Purnomo Santosa.

Dimana menurut Bapak Irwan S.H., M.Kn Notaris di Tangerang sebagai narasumber penulis berpendapat PT. Intan Plaza Adika yang dapat dikatakan sebagi pembeli beritikad baik dapat mengajukan perlindungan sebagaimana diatur dalam Surat Edaran Mahkamah Agung (SEMA) Nomor 7 Tahun 2012 butir ke-IX yang menjelaskan mengenai perlindungan harus diberikan kepada pembeli yang beritikad baik sekalipun kemudian diketahui bahwa penjual merupakan orang yang tidak berhak terkait objek jual beli. Sehingga menurut penulis PT. Intan Plaza sebagai pembeli dapat mendapat perlindungan berasarkan SEMA tersebut. ${ }^{6}$

\section{Penutup}

\section{A. Kesimpulan}

Penulis menyimpulkan bahwa PPJB yang dilakukan antara PT. Intan Plaza Adika selaku pembeli dengan Koko Purnomo Santoso selaku penjual memenuhi Pasa1 1320 KUH Perdata mengenai syarat sahnya perjanjian karena perjanjian dibuat memenuhi syarat subjektif dan syarat objektif dimana syarat subjektif yang pertama kesepakatan antara keduanya merupakan pihak-pihak yang melakukan perjanjian yang tertuang sesuai dengan identitas para pihak yang tertuang dalam PPJB, serta yang kedua kecakapan para pihak telah memenuhi syarat cakap dalam segi umur, tidak dibawah pengampuan atau sehat pikirannya. Syarat objektif yang pertama yaitu suatu hal tertentu telah terpenuhi.

Mengenai pengertian pembeli beriktikad baik sebagaimana tercantum dalam Surat Edaran Mahkamah Agung Nomor 5 Tahun 2014. Kriteria pembeli yang beritikad baik yang perlu dilindungi berdasarkan Pasa1 1338 ayat (3) KHU Perdata adalah sebagai berikut:

6) Peneliti, Wawancara, dengan Notaris di Tangerang, (Tangerang: Kantor Notaris, 30 Oktober 2019). 
Volume 2 Nomor 2, Desember 2019

E-ISSN : 2655-7347

a. Melakukan jua1 beli atas objek tanah tersebut dengan tata cara/prosedur dan dokumen yang sah sebagaimana telah ditentukan peraturan perundang-undangan.

b. Melakukan kehati-hatian dengan meneliti hal-hal berkaitan dengan objek tanah yang diperjanjikan.

Pembelian terhadap objek atas tanah yang dilakukan antara Koko Purnomo Santoso dengan PT. Intan Plaza Adika dilakukan secara tunai dan terang, akan tetapi tidak di depan Kepala Desa setempat, melainkan dihadapan Notaris sebagai Pejabat Umum setelah Kepala Desa setempat yang telah memberikan Surat Keterangan bahwa objek adalah benar milik Koko Purnomo Santoso serta nama lain yang memberikan kuasa menual kepada Koko Purnomo Santoso.

Bahwa dalam kasus ini Koko Purnomo Santoso adalah orang yang berhak/memiliki hak atas tanah yang menjadi objek jual beli, sesuai dengan bukti kepemilikannya dan dokumen-dokumen kepemilikan asli, tidak dalam bentuk salinan maupun dipalsukan yang diserahkan kepada PT. Intan Plaza Adika, dan tanah/objek yang diperjualbelikan tersebut tidak dalam status disita, dan Tanah/objek yang diperjualbelikan tidak dalam status jaminan/Hak Tanggungan.

Berdasarkan SEMA Nomor 5 Tahun 2014 mengenai kriteria pembeli beritikad baik telah dipenuhi oleh PT. Intan Plaza Adika sebagai pihak pembeli harus dilindungi. Sehingga PPJB antara para pihak sah dan tidak memiliki cacat hukum. Kasus pidana yang dilakukan Koko Purnomo Santoso diputus tahun 2008 yang membuat Koko Purnomo Santoso dipenjara 4 (empat) tahun penjara tidak mengakibatkan PPJB tersebut tidak memenuhi syarat sahnya perjanjian. Berdasarkan SEMA Nomor 7 Tahun 2012 butir ke-IX yang menjelaskan mengenai perlindungan harus diberikan kepada pembeli yang beritikad baik sekalipun kemudian diketahui bahwa penjual merupakan orang yang tidak berhak terkait objek jua1 beli. Harus diberikan kepada PT. Intan Plaza Adika. 
Volume 2 Nomor 2, Desember 2019

E-ISSN : 2655-7347

\section{B. Saran}

Sebaiknya PT. Intan Plaza Adika sebagai pembeli dapat lebih teliti melihat subjek jual beli yaitu penjual dan objek jua1 beli yaitu bidangbidang tanah yang akan dilakukan transaksi jual beli, selain itu sebagai pembeli haruslah menyelidiki secara lebih lanjut mengenai asal usul dan riwayat kepemilikan tanah ke kantor pejabat yang terkait mengenai pertanahan dan membuat pernyataan bebas sengketa terlebih dahulu. Sehingga syarat-syarat administrasi dapat terpenuhi dan tidak terjadi pemaksaan hukum dalam melakukan transaksi jua1 beli.

Mengenai PPJB yang dibuat dalam jual beli bukan merupakan akta peralihan hak sehingga apabila dilihat PPJB ini seharusnya dilanjutkan dengan Akta Jua1 Beli dan sehubung adanya syarat-syarat untuk melakukan Akta Jua1 Beli yang mungkin belum terpenuhi oleh pembeli seharusnya pembeli dapat memenuhi segera syarat-syarat untuk melakukan Akta Jua1 Beli sehingga peralihan hak terlaksana dan tidak menimbukan kerugian bagi pihak pembeli.

\section{Daftar Pustaka}

\section{A. Buku}

Adjie, Habib. Hukum Notaris Indonesia (Tafsir Tematik Terhadap UU No. 30 Tahun 2004 tentang Jabatan Notaris). Cetakan ke- 4.

(Bandung: Refika Aditama, 2014).

. Kebatalan dan Pembatalan Akta Notaris. Cetakan ke-3.

(Bandung: Refika Aditama, 2015).

Amirudin dan Zainal Asikin. Pengantar Metode Penelitian Hukum. (Jakarta: Raja Grafindo Persada, 2004).

Andasasmita, Komar. Notaris Selayang Pandang. (Bandung: Alumni, 1983).

Budiono, Herlien. Kumpulan Tulisan Hukum Perdata Di Bidang Kenotariatan. Buku Kesatu. Cetakan ke-4. (Bandung: Citra Aditya Bakti, 2016). 
E-ISSN : 2655-7347

Fajar, Mukti dan Yulianto Achmad. Dualisme Peneitian Hukum Normatif dan Empiris. (Yogyakarta: Pustaka Pelajar, 2015).

Hadjon, Philipus M. Perlindungan Hukum Bagi Rakyat Indonesia. (Surabaya: Bina Ilmu, 1987).

Haris, Freddy dan Leny Helen. Notaris Indonesia. Cetakan ke-2. (Jakarta: Lintas Cetak Djaja, 2017).

Harsono, Boedi. Hukum Agraria Indonesia Sejarah: Pembentukan Undang-Undang Pokok Agraria, Isi dan Pelaksanaannya. (Jakarta: Djambatan, 2008).

HS, Salim. Perkembangan Hukum Kontrak diluar KUH Perdata. (Jakarta: Raja Grafindo Persada, 2007). Hukum Kontrak. Teori dan Teknik Penyusunan Kontrak. Cetakan ke-9. (Jakarta: Sinar Grafika, 2013). . Teknik Pembuatan Akta Perjanjian (TPA Dua). (Jakarta: Raja Grafindo Persada, 2017).

H.S, Salim dan Erlies Septiana Nurbani. Penerapan Teori Hukum Pada Penelitian Tesis Dan Disertasi. Cetakan ke-1. (Jakarta: Raja Grafindo Persada, 2013).

Khairandy, Ridwan. Itikad Baik Dalam Kebebasan Berkontrak, (Yogyakarta: FH UI, 2014).

Kie, Tan Thong. Studi Notariat dan Serba-Serbi Praktek Notaris. Cetakan ke-2 (Jakarta: Ichtiar Baru Van Hoeve, 2011).

Marzuki, Peter Mahmud. Penelitian Hukum. (Jakarta: Kencana Prenada Media Group, 2006).

Mertokusumo, Sudikno. Mengenal Hukum Suatu Pengantar. (Yogyakarta: Liberty, 1999).

Muhammad, Abdulkadir. Hukum Perikatan. (Bandung: Citra Aditya Bakti, 1990).

Muhammad, Busher. Pokok-Pokok Hukum Adat. Cetakan Ke-7, (Jakarta: Pradnya Paramita, 2000). 
E-ISSN : 2655-7347

Prodjodikoro, Wirjono. Hukum Perdata Tentang Persetujuanpersetujuan Tertentu. (Bandung: Sumur, 1981).

Rasyidi, Lili. Filsafat Hukum. (Bandung: Remadja karya, 1988).

Saleh, K. Wantijk. Hak Anda Atas Tanah. (Jakarta: Ghalia Indonesia, 1982).

Satrio, J. Hukum Perjanjian. (Bandung: Citra Aditya Bakti, 1992). , Hukum Perikatan (perikatan yang lahir dari undang-undang). (Bandung : Citra Aditya Bakti).

Soekanto, Soerjono Metode Penelitian Hukum. Cetakan ke-3. (Jakarta: UI Press, 1984).

Subekti, Pokok-Pokok Hukum Perdata. Cetakan ke-31. (Jakarta: Intermasa, 2003). , Hukum Perjanjian. Cetakan ke-19. (Jakarta: Intermasa, 2002).

Syaifuddin, Muhammad. Hukum Kontrak. (Bandung: Mandar Maju, 2012).

Syarif, Elza. Menuntaskan Sengketa Tanah Melalui Pengadilan Khusus Pertanahan. (Jakarta: Kepustakaan Populer Gramedia, 2012).

Tanuwidjaja, Henny. Pranata Jaminan Utang dan sejarah Lembaga Hukum Notariat. (Bandung: Refika Aditama, 2012).

\section{B. Peraturan Perundang-Undangan}

Indonesia. Undang-Undang Republik Indonesia Nomor 5 Tahun 1960 tentang Peraturan Dasar Pokok-Pokok Agraria (Lembaran Negara 1960-104, Tambahan Lembaran Negara Nomor 2043).

Subekti, R. dan R. Tjitrosudibio. Kitab Undang-Undang Hukum Perdata. Cetakan Ke-27. Edisi Revisi. (Jakarta: Pradnya Paramita, 1995).

\section{Kamus}

Departemen Pendidikan dan Kebudayaan. Kamus Besar Bahasa Indonesia. Edisi Kedua. (Jakarta: Balai Pustaka, 1995).

Sudarsono. Kamus Hukum. (Jakarta: Rineka Cipta, 1992). 


\section{Jurnal}

Arnita Simamora, Novalia. et al. "Asas Itikad Baik Dalam Perjanjian Pendahuluan (Voor Overeenkomst) Pada Perjanjian Pengikatan Jua1 Beli Rumah (Studi Putusan Pengadilan Negeri Simalungun No 37/Pdt/Plw/2012/Sim)". USU Law Journal. Volume 3, No.3 Tahun 2015.

Firdaus, Riza. "Perlindungan Hukum Bagi Pembeli Dalam Perjanjian Pengikatan Jua1 Beli Tanah Yang Masih Berstatus Hak Pengelolaan". Lambung Mangkurat Law Journal. Volume 2, Issu 1 Tahun 2017.

Hadi, Gary. et al. "Penerapan Asas Itikad Baik Dalam Perjanjian SewaMenyewa (Studi Terhadap Perjanjian Sewa Menyewaisepiet Di Hermes Building Medan)". USU Law Journal. Volume 5, No.2 Tahun 2017.

Innaka, Antari. et al. "Penerapan Asas Itikad Baik Tahap Prakontraktual Pada Perjanjian Jua1 Beli Perumahan”. Mimbar Hukum. Volume 24, No.3.

\section{E. Putusan}

Putusan Pengadilan Negeri Jakarta Timur Nomor: 117/Pdt.G/2014/PN.Jkt.Tim.

Putusan Pengadilan Tinggi Jakarta Nomor: 117/PDT/2015/PT.DKI.

Putusan Kasasi Mahkamah Agung Nomor: 17K/Pdt/2016.

Putusan Peninjauan Kembali Nomor: 534PK/Pdt/2017. 